\title{
A Case of Septic Arthritis of Shoulder Joint Due to Streptococcus anginosus Following Dental Treatment
}

\section{öz}

Romatolojik acil durumlar içinde sınıflanan septik ya da piyojenik artrit olarak da bilinen bakteriyel artritler erken tanı konulamaz ve uygun tedavi yapılamazsa kalıcı eklem harabiyetine yol açabilmektedir. Enfeksiyonun oluşma yolu ve hastaya bağlı risk faktörlerine göre enfeksiyon etkenleri değişkenlik gösterir. Tüm olgularda en sık görülen etkenler \% 75-80 oranında Gram pozitif koklardır ancak immün yetmezlik, iv ilaç alışkanlığı, ileri yaşlar veya iatrojenik olgularda gram negatif basiller de etken olabilirler.

Streptococcus anginosus grubu bakteriler hareketsiz, fakültatif anaerop, diğer tüm streptokoklar gibi katalaz negatif gram pozitif koklar olup özellikle ağız boşluğu olmak üzere tüm gastrointestinal sistemin normal florasında bulunur. S.anginosus'a bağlı enfeksiyonların diğer streptokok enfeksiyonlarından farklı olarak en önemli karakteristiği apse oluşturma eğilimidir ve diğer düşük virülanslı streptokoklardan farklı olarak izolasyonunda gerçek patojen olarak kabul edilmelidir. Diş apseleri, gingivit gibi minör oral kavite enfeksiyonlarından, derin boyun enfeksiyonlarına, metastatik akciğer, karaciğer, beyin apselerine yol açabilmektedir. Literatürde kemik ve eklem tutulumu çok nadiren bildirilmiştir.

Bu sunumda sol omuzda șislik ve ağrı sikayeti ile bassvuran immün kompetan, 64 yașındaki kadın hastada, diş tedavisinden bir ay sonra gelişen septik artrit tablosu bildirilmektedir. Hastanın başvurusundaki sinoviyal sIVI incelemesinde 26,000 lökosit/ $/ \mathrm{mm}^{3}, \% 82$ polimorfonükleer lökosit saptanması ve gram boyamada mikroorganizma görülmemesi üzerine ampirik piperasilintazobaktam+daptomisin iv tedavisi başlanmıştır. Kültür sonucunda dördüncü günde S.anginosus üremesi saptanınca piperasilin-tazobaktam kesilip tedaviye iv daptomisin ile devam edilerek 14 güne tamamlanmıştır. Hasta amoksisilin-klavulanik asit $1000 \mathrm{mg} 2 \times 1$ oral antibiyoterapi ile taburcu edilmiş, iki hafta sonunda kontrolünde klinik iyileşme saptanarak tedavisi sonlandırılmıştır.

Anahtar kelimeler: diş tedavisi, septik artrit, Streptococcus anginosus

\section{ABSTRACT}

Septic arthritis is classified in acute rheumatologic emergencies and prompt diagnosis and treatment is critical for prognosis since the infection may lead to permanent destruction. Etiology varies due to routes of infection and host factors. Gram positive cocci are responsible in most of the cases (75-80\%) but in case of immune supression, elderly patients, intravenous drug usage and iatrogenic cases, Gram negative bacilli may also be involved.

S.anginosus group are non-motile, facultative anaerobe and catalase-negative Gram-positive cocci that are recognized as normal flora of the human oral cavity and gastrointestinal tract. The unique characteristic of the S.anginosus group that sets these streptococci apart from other pathogenic streptococci is their ability to cause abscesses and should be considered as true pathogens when isolated. Infections vary from dental abscesses, gingivitis and other periodontal infections to deep neck infections, metastatic lung, liver, intra-abdominal and brain abscesses. In the literature soft tissue infections, septic arthritis and osteomyelitis are very rarely reported. In this case report we present a case of septic arthritis due to S.anginosus in an otherwise immunocompetant 64 year old woman that presented with pain and swelling of the left shoulder one month after a dental treatment. The sinoviyal fluid analyses revealed a WBC count of 26,000/ $\mathrm{mm}^{3}$ with $82 \%$ polymorphonuclear leukocytes with a negative Gram stain. The patient was started on ampirical intravenous treatment with piperacilin-tazobactam and daptomycine. At the fourth day, the synovial fluid culture results yielded S. anginosus, then piperacilin-tazobactam was stopped and daptomycine continued till the 14th day. The patient was discharged with oral amoxiciline-clavulanic acid $1 \mathrm{gr} /$ day for 14 days. After two weeks the therapy was stopped due to clinical improvement.

Keywords: dental treatment, septic arthritis, Streptococcus anginosus \begin{tabular}{r}
\hline Alındığı tarih: 17.01 .2019 \\
Kabul tarihi: 25.04 .2019 \\
Yayın tarihi: 30.04 .2019
\end{tabular}

Ali llgın Olut

S.B.Ü. İzmir Bozyaka Eğitim Araştırma Hastanesi, Enfeksiyon Hastalıkları ve Klinik Mikrobiyoloji Kliniği İzmir - Türkiye - iolut@yahoo.com ORCID: 0000-0003-4129-6453

F. Balaylar 0000-0001-1884-2121 S.B.Ü. Izmir Bozyaka EAH Enfeksiyon Hastalıkları ve Klinik Mikrobiyoloji Kliniği Izmir - Türkiye

M. U. Çayıröz 0000-0002-5493-5499 Bucak Devlet Hastanesi Burdur - Türkiye

T. Altay 0000-0002-6917-934X S.B.Ü. Izmir Bozyaka EAH Ortopedi ve Travmatoloji Kliniği İzmir - Türkiye 


\section{GiRiş}

Septik artrit, eklemlerdeki sinoviyal zar ve sinoviyal sıvının (SS) bakteriyel, viral ya da fungal etkenlerle oluşan iltihabıdır. Sinoviyal zar oldukça vasküler bir yapıdır ancak koruyucu bazal membranı olmadığı için mikroorganizmaların kolaylıkla yerleşmesi için uygun bir alan teşkil eder(18).

Bakteriler eklem ve eklem sinoviyasına en sık olarak vücuttaki diğer bir enfeksiyon odağından hematojen yolla, daha seyrek olarak da lokal travma (açık kırıklar, eklem içi cerrahi girişimler, artroplasti ameliyatları vs.) veya osteomiyelit, selülit, bursit gibi komşu bir enfeksiyon odağından gelirler. En sık tutulan eklem \% 45 oranında diz eklemidir ve bunu kalça, ayak bileği, dirsek, el bileği ve omuz eklemleri takip eder ${ }^{(16,17)}$. Septik artrit atağı akut bir tablodur. Olgularda genellikle ateş yükselmesi, halsizlik, iştahsızık, bulantı vb. sistemik bulgulara ek olarak eklemde şişlik, kızarıklık, sıcaklık artışı, hassasiyet ve hareket kısıtlılığı gibi lokal inflamasyon bulguları vardır. Kesin tanı sinovyal sıvının steril koşullarda aspire edilerek makroskopik, mikroskopik, mikrobiyolojik ve biyokimyasal değerlendirilmesi ile konulur. Sinovyal sıvıdaki lökositlerin $50,000 / \mathrm{mm}^{3}$ üzerinde ve polimorf çekirdekli lökositlerin \% 80 üzerinde olması akut bakteriyel enfeksiyon lehinedir ${ }^{(11)}$. Hücre sayısının 20,000-50,000/ $\mathrm{mm}^{3}$ arasında olması tanıyı zorlaştırabilir, lökosit sayısının 20,000/ $\mathrm{mm}^{3}$ ün altında olması ise enfeksiyon olasılığını azaltır(11). Gram boyaması ile Gram pozitif bakteriler \% 75-80, Gram negatif bakteriler $\%$ 40-50, gonokoklar ise \% 20-25 oranında gözlenebilir. SS'de etken üretme oranı ise ortalama \% 60 civarındadır ve \% 14'lük bir kısımda ek olarak kan kültürü ile tanı konulmaktadır. Bu yüzden SS'ya ek olarak kan kültürü alınması da önemlidir ${ }^{(11)}$.

Oral ve gastrointestinal sistemin normal florasında bulunan ve çoğunlukla ağız içinde lokal enfeksiyonlara yol açan S.anginosus suşu bakteremi ile birlikte genellikle apse oluşumu ile karakterize sistemik enfeksiyonlara yol açabilir ${ }^{(9)}$. Bununla birlikte kas ve iskelet sistemi tutulumu oldukça nadir olarak bildirilmektedir ${ }^{(9)}$. Bu olgu sunumunda 64 yaşında kadın hastanın sol omzunda diş tedavisini takiben bir ay sonra gelişen S.anginosus'a bağlı septik artrit bildirilmektedir.

\section{OLGU}

Altmış dört yaşında kadın hasta sol omuzda bir haftadır olan ağrı, şişlik ve hareket kısıtlılığı nedeniyle başvurmuştur. Travma öyküsü olmayan hastanın anamnezinde yaklaşık bir ay önce diş tedavisi yaptırdığı öğrenilmiştir.

Fizik muayenesinde vücut sıcaklığı $36.4^{\circ} \mathrm{C}$ saptanırken, sistemik enfeksiyon hastalığına ait muayene bulgusu saptanmamıştır. Hareket sistemi muayenesinde sol omuz hareketleri kısıtlı ve ağrılı olduğu gözlenmiştir. Diğer eklemlerin muayenesi olağan bulunmuştur. Rutin laboratuvar incelemesinde tam kan sayımında lökosit: $6130 / \mathrm{mm}^{3}$, C-reaktif protein (CRP): $146 \mathrm{mg} / \mathrm{L}$, sedimentasyon $132 \mathrm{~mm} / \mathrm{saat}$, kan biyokimyasında karaciğer ve böbrek fonksiyonları normal sınırlarda saptanmıştır. Sol omuz eklem grafisinde dejeneratif değişiklikler ve eklem aralığında artışı olduğu görülmüştür (Resim). Hastanın sol omuz ekleminden steril koşullar altında $20 \mathrm{ml}$ sinovyal SIVı aspire edilmiştir. SS incelemesinde 26.000 lökosit/mm $/ \mathrm{mm}^{3}$ \% 85 polimorfonükleer lökosit saptanması ve Gram boyamada bakteri gözlenmemesi üzerine ampirik olarak piperasilintazobaktam $3 \times 4.5 \mathrm{~g} /$ gün iv ve daptomisin $1 \times 400$ $\mathrm{mg} / g u ̈ n$ iv başlanmıştır. Hastanın SS kültüründe dördüncü günde Streptococcus anginosus üremesi saptanınca piperasilin-tazobaktam kesilip tedaviye daptomisin ile devam edilmiştir. Damar içi antibiyoterapisi 14 güne tamamlanan hastada kontrol CRP: $21 \mathrm{mg} / \mathrm{L}$, sedimentasyon $56 \mathrm{~mm} / \mathrm{saat}$ olarak saptanması ve enfeksiyon kliniğinde belirgin gerileme olması üzerine oral amoksisilin/klavulanik asit 1000 mg 2x1 14 gün kullanım önerisi ile taburcu edilmiştir. Taburculuktan 14 gün sonrasındaki kontrolünde sol omuzdaki ağrı ve hareket kısıtıılığının gerilemesi ve CRP değerinin $5 \mathrm{mg} / \mathrm{L}$ düşmesi üzerine tedavi sonlandırılmıştır. Hastanın 30 gün sonraki kontrolünde eklemde ağrı ve hareket kısıtlılığı gözlenmemiştir. 


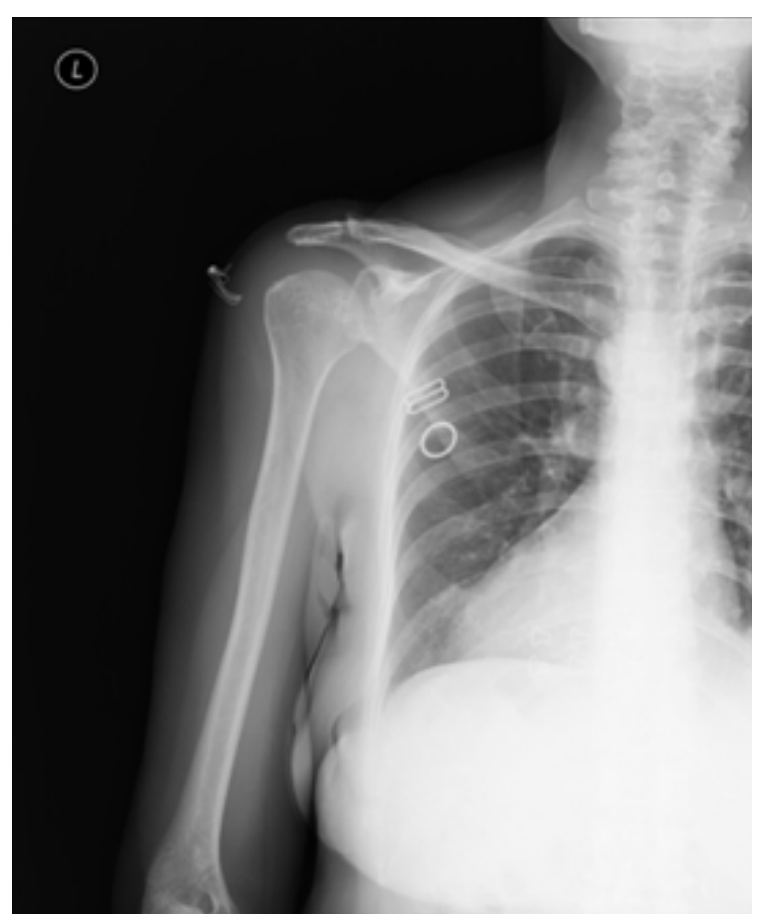

Resim. Sol omuzu tutan septik artrit ve çevre yumuşak dokuda yaygın ödem.

\section{TARTIŞMA}

Septik artrit etiyolojisinde en sıklıkla Gram pozitif bakteriler sorumlu tutulmakta ve olguların yaklaşık \% 80'ini oluşturmaktadır. Özellikle Staphylococcus aureus extraselüler matriks proteinlerine bağlanan yüzeyel adezyon molekülleri içerdiğinden septik artritlerin en sık etkenidir ${ }^{(8)}$.

Streptokokkal septik artritler non-gonokokal septik artritlerin \% 15-30'unu oluşturmakta ve çoğunlukla Streptococcus pyogenes (Grup A), Streptococcus agalactiae (Grup B) ve pnömokoklara bağlı gelişmektedir ${ }^{(3,8)}$. Viridans streptokoklar, özellikle ağız ve gastrointestinal sistem florasında yer alan düşük patojeniteye, yüksek antimikrobiyal duyarlığa sahip Gram pozitif koklardır. Diş çürükleri ve enfektif endokarditin başlıca etkenlerinden olmalarına karşılık septik artrit etyolojisinde nadiren yer almaktadırlar ${ }^{(1)}$. Kapsamlı yorum ve derlemelerde etkenler arasında sayılmamakla birlikte diz, çene, sternoklavikular, sakroiliak eklemlerin tutulduğu olgular bildirilmekte$\operatorname{dir}^{(6,8,14,19)}$.

Viridans grubu üyeleri arasında olan S.anginosus enfeksiyonları genellikle ağız içi, baş boyun, pulmoner ve intraabdominal yerleşimli olup tipik olarak apse oluşumu ile karakterizedir ${ }^{(9,12)}$. Çok nadir olarak septik artritte izole edilmişlerdir ${ }^{(3)}$. Literatürde S.anginosus'a bağlı beş adet olgu bildirilmiştir(4,7,10,20,22). Olgulardan üçü diz, biri sternoklavicular ve biri de supraklavikular eklem tutulumu olup üç olguda önemli derecede predispozan durum bildirilmiştir (bir hastada romatoid artrit, bir hastada steroid tedavisi, bir hastada gut, diabetes mellitus ve steroid tedavisi). Beş hastanın dördüne cerrahi drenaj yapılmış, dört hasta penisilin, bir hasta da üç hafta ampisilin tedavisini takiben altı hafta sefazolin ile tedavi görmüştür. Sternoklavikular ve supraklavikular eklem tutulumu olan hastalar tümüyle iyileşmiş, diz tutulumu olan üç hastada enfeksiyon temizlenmesine rağmen kalıcı eklem destrüksiyonuna bağlı hareket kısıtlılığı devam etmiştir ${ }^{(7,10)}$.

Literatürde diş tedavisini takiben gelişen septik artrit olguları yer almaktadır ancak bunların büyük kısmı protez eklemlerde görülmekte ve tedavi sonraSı oluşan bakteremiye bağlı geliştiği öngörülmektedir $^{(2,5,13,21)}$. Al Himdani ve ark. ${ }^{(1)}$ kanal tedavisini takiben gelişen grup $\mathrm{C}$ streptokoklara bağlı kalça eklem artriti rapor etmişler ve literatürde yer alan benzer olguları da göz önüne alarak eklem protezi olan hastalara diş tedavisinden iki saat önce ve dört saat sonra oral $625 \mathrm{mg}$ amoksisilin-klavulanik asit ile profilaksi önermişlerdir.

Diş tedavisini takiben doğal eklemde gelişen septik artrit çok nadiren bildirilmiştir. Papaioannides ve ark. ${ }^{(14)}$ ve Patrick ve ark. ${ }^{(15)}$ invazif bir diş tedavisini takiben üçüncü ve dördüncü haftalarda gelişen Streptococcus sanguinis'e bağı ı iki diz eklem artriti bildirmişler ve yakın zamanda diş tedavisi sonrası gelişen septik artritlerde oral streptokokların da ön planda düşünülmesi gerektiğini vurgulamışlardır. Olgumuz literatürde S.anginosus'a bağlı rapor edilen altıncı septik artrit olup diş tedavisini takiben gelişen ilk olgudur. Son olgu Balentine ve ark. ${ }^{(2)}$ tarafından 1989 'da bildirilmiş, yazarlar üç haftalık damar içi ampisilin ile tedavi ettikleri ve sonrasında akut rekürrens ve sepsis ile başvuran olgularını ve literatürdeki olguların göreceli olarak yüksek morbidite ile seyret- 
mesini göz önüne alarak tedavinin altı haftaya tamamlanmasını önermişlerdir. Olgumuz iki hafta damar içi iki hafta da oral tedavi ile iyileşme saptanmış olup sonrasında rekürrens gözlenmemiştir. Ancak immün supresif durumunun veya eklemi ilgilendiren predispozan faktörlerin bulunmaması göz ardı edilmemelidir.

Sonuç olarak, oral viridans streptokoklara bağlı septik artritlerin, oldukça nadir görülmekle ve kapsamlı rehberlerde etkenleri arasında yer almamakla birlikte yakın zamanda diş tedavisi sonrası gelişen septik artritlerde olası etkenler arasında ön planda akla gelmesi gerektiğini düşünmekteyiz.

Çıkar Çatışması: Yazarlar tarafından herhangi bir çıkar çatışması bildirilmemiştir.

Conflict of Interest: No conflict of interest was declared by the authors.

\section{KAYNAKLAR}

1. Al-Himdani S, Woodnutt D. Group C streptococcal septic arthritis of a prosthetic hip joint following dental treatment. BMJ Case Rep. 2015;22:1-4. https://doi.org/10.1136/bcr-2015-211203

2. Balentine LT, Papasian CJ, Burdick C. Septic arthritis of the knee due to Streptococcus anginosus. Diagn Microbiol Infect Dis. 1989;12(2):189-91. https://doi.org/10.1016/0732-8893(89)90012-6

3. Blankstein A, Amsallem JL, Rubinstein E, et al. Septic arthritis of the acromioclavicular joint. Arch Orthop Trauma Surg. 1985;103(6):417-8. https://doi.org/10.1007/BF00435451

4. Edson RS, Osmon DR, Berry DJ. Septic arthritis due to Streptococcus sanguis. Mayo Clin Proc. 2002;77(7):709-10. https://doi.org/10.4065/77.7.709

5. Fazili T, Riddell S, Kiska D, et al. Streptococcus anginosus group bacterial infections. Am J Med Sci. 2017;354(3):257-61. https://doi.org/10.1016/j.amjms.2017.05.011

6. Goldenberg DL, Reed JI. Bacterial arthritis. N Engl J Med. 1985;312(12):764-71. https://doi.org/10.1056/NEJM198503213121206

7. Houston BD, Crouch ME, Finch RG. Streptococcus MG-intermedius (Streptococcus milleri) septic art- hritis in a patient with rheumatoid arthritis. J Rheumatol. 1980;7(1):89-92.

8. Hynd RF, Klofkorn RW, Wong JK. Streptococcus anginosus-constellatus infection of the sternoclavicular joint. J Rheumatol. 1984;11(5):713-5.

9. Jacobson JJ, Matthews LS. Bacteria isolated from late prosthetic joint infections: dental treatment and chemoprophylaxis. Oral Surg Oral Med Oral Pathol. 1987;63(1):122-6. https://doi.org/10.1016/0030-4220(87)90352-5

10. Johnson CC, Tunkel AR. Viridans streptococci, groups $C$ and $\mathrm{G}$ streptococci, and Gemella morbillorum, "Mandell GL, Bennett JE, Dolin R (eds): Mandell, Douglas, and Bennett's Principles and Practice of Infectious Diseases 6.baskı" kitabında s.2434-51, Churchill Livingstone, Philadelphia (2005).

11. Kaandorp CJ, Dinant $\mathrm{HJ}$, van de Laar MA, et al. Incidence and sources of native and prosthetic joint infection: a community based prospective survey. Ann Rheum Dis. 1997;56(8):470-5. https://doi.org/10.1136/ard.56.8.470

12. Lever AM, Owen T, Forsey J. Pneumoarthropathy in septic arthritis caused by Streptococcus milleri. $\mathrm{Br}$ Med J. 1982;285(6334):24. https://doi.org/10.1136/bmj.285.6334.24

13. Maderazo EG, Judson S, Pasternak $\mathrm{H}$. Late infections of total joint prostheses: a review and recommendations for prevention. Clin Orthop. 1988;229(229):13142.

https://doi.org/10.1097/00003086-198804000-00017

14. Papaioannides D, Boniatsi L, Korantzopoulos P, et al Acute septic arthritis due to Streptococcus sanguis. Med Princ Pract. 2006;15(1):77-9. https://doi.org/10.1159/000089391

15. Patrick MR, Lewis D. Short of a length: Streptococcus sanguis knee infection from dental source. $\mathrm{Br} J$ Rheumatol. 1992;31(8):569. https://doi.org/10.1093/rheumatology/31.8.569-a

16. Peters RH, Rasker JJ, Jacobs JW, et al. Bacterial arthritis in a district hospital. Clin Rheumatol. 1992;11(3):351-5. https://doi.org/10.1007/BF02207192

17. Pioro $M H$, Mandell BF. Septic arthritis. Rheum Dis Clin North Am. 1997;23(2):239-58. https://doi.org/10.1016/S0889-857X(05)70328-8

18. Ross JJ. Septic arthritis of native joints. Infect Dis Clin North Am. 2017;31(2):203-18. https://doi.org/10.1016/j.idc.2017.01.001

19. Seviour PW, Dieppe PA. Sternoclavicular joint infecti- 
A. I. Olut ve ark., Diş Tedavisini Takiben Gelişen, Streptococcus anginosus'a Bağlı, Omuz Eklemi Tutan Bir Septik Artrit Olgusu

on as a cause of chest pain. Br Med J. 1984;288(6411): 133-4.

https://doi.org/10.1136/bmj.288.6411.133

20. Stratton CV, Sexton D, Baron EL. Infections due to the Streptococcus anginosus (Streptococcus milleri) group. Uptodate, Literature review current through Nov 2018.

21. Sullivan PM, Johnston RC, Kelley SS. Late infection after total hip replacement, caused by an oral organism after dental manipulation: a case report. J Bone Joint Surg Am. 1990;72:121-3. https://doi.org/10.2106/00004623-199072010-00019

22. Vartian C, Lerner PI, Shlaes DM, et al. Infections due to Lancefield group G streptococci. Medicine (Baltimore) 1985;64(2):75-88.

https://doi.org/10.1097/00005792-198503000-00001 